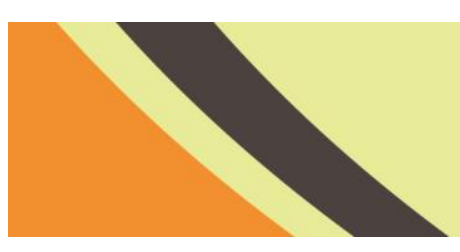

\title{
AJARCDE
}

ASIAN JOURNAL OF APPLIED RESEARCH FOR COMMUNITY DEVELOPMENT AND EMPOWERMENT

\section{Improving the Quality of Tilapia Fish Seeds (Oreochromis Niloticus) with Selection Methods in Mina Ayu Group of Tabanan Regency Bali Province}

\author{
S.A.M.P. Suryani ${ }^{1}$, Faihana Ching Abdulah ${ }^{2}$, Norfazreena Mohd Faudzi ${ }^{2}$, D.N.Sadguna ${ }^{1}$, \\ I Wayan Arya ${ }^{1}$, D.G.Semara Edi ${ }^{1}$, G.A Surya Pratama ${ }^{1}$ \\ ${ }^{I}$ Water Resources Management Study Program, Faculty of Agriculture, Warmadewa University, Denpasar. Indonesia. \\ ${ }_{2}^{2}$ Institut Penyelidikan Marine Borneo, University Malaysia Sabah. Malaysia.
}

\section{ARTICLE INFO}

\section{Article History:}

Received: 21 December 2021

Final Revision: 17 January 2022

Accepted: 12 February 2022

Online Publication: 09 February 2022

\section{KEYWORDS}

Oreochromis niloticus, selective breeding, hatchery, tilapia, community service program

\section{CORRESPONDING AUTHOR}

*E-mail: suryanip@ rocketmail.com

\section{A $\quad$ B $\mathbf{S}$ T $\mathbf{R}$ A $\mathbf{C}$ T}

\begin{abstract}
The demand for tilapia fish is increasing as it has several advantages such as its distinctive taste that makes tilapia delicious after being processed in any way. Tilapia has the potential to be used as an export commodity in the form of fish fillets and the price is relatively cheap. The climate situation and the extent of freshwater fishing land are contributing factors in the development of tilapia cultivation in Indonesia. One of the efforts to increase efficiency and productivity in cultivation is fish spawning activities. Spawning activities are important for producing seeds or larvae. Female fish are 300 to $400 \mathrm{~g}$ and for males, 400 to $500 \mathrm{~g}$, aged 5 months. Tilapia can colonize weighing $250 \mathrm{~g}$ and age 4 to 6 months, meaning the parent used in this study has been following the required. The maintained parent is a healthy, unformed, and complete morphological parent (SNI 01-61412009). The purpose of this study is to improve the quality of Tilapia fish seeds produced by the Mina Ayu Group of Tabanan Regency Tabanan Village of Bali Province by a selective breeding method. Male and female tilapia broods are kept separately in hapa measuring $5 \times 5 \times 1 \mathrm{~m}$. In shelters, for the acceleration of gonad maturation before the fish are stocked in the spawning pond. The feeding given during maintenance is 2 to $3 \%$. Individual selection methods can improve the quality and survival rate of tilapia fish larvae. The absolute length increased $1.5 \mathrm{~cm}$ and weight increased 0.950 $\mathrm{mg}$ /day with a survival rate of $80 \%$ to $90 \%$.
\end{abstract}

\section{INTRODUCTION}

\subsection{Research Background}

The production of the fishery sector, especially tilapia, has increased from year to year. According to the Ministry of Marine and Fisheries, tilapia production in 2016 amounted to $1,114,156$ tons, in 2017 and 2018 tilapia production again increased by $1,265,201$ tons, and 1,169,144 tons, respectively [1]. The high volume of exports is an opportunity that can be utilized by stakeholders, related to the development of alternative commodities to be more varied. This can boost the development of fish farming in Indonesia.

Tilapia fish cultivation in Indonesia has increased a lot with the emergence of several strains of tilapia fish breeding results. Tilapia (Oreochromis niloticus) is one of the most popular freshwater commodities in meeting daily protein needs. [2,3]. The prospects for the development of tilapia cultivation in Indonesia are quite bright. This can be seen from the high interest of the public towards tilapia fish. One type of tilapia fish that is quite developed in Indonesia is the red tilapia oreochromis sp.[4]. Tilapia red tilapia is a hybrid fish made by crossing consisting of 16 combinations that are combined into synthetic populations. Tilapia Oreochromis sp. is a genus of fish that can live in environmental conditions that have a high tolerance to low water quality. Tilapia became an export commodity in place of red sea bream Chrysophrys major marine fish, favored by the world's consumers because it has an attractive meat color, delicious taste and does not have thorns between muskulars. [5]. The improvement in the quality of tilapia seeds depends largely on the quality of the parent. A superior parent can be obtained by doing tilapia selection that is maintained by cultivators as a candidate for quality parent (selective breeding). This selective breeding method is applied to Community Service Activities (CSA) in community groups engaged in the cultivation of Tilapia Fish. Mina Ayu's group started its business in 2015. The members of this group consist of 15 people, most of whom are new villages who have a desire to entrepreneurship in the field of fisheries. Their motivation to pursue business in the field of fisheries starts from the potential of land in this village is very supportive to do the business. 


\subsection{Literature Review}

Breeding activities that are currently growing rapidly in Indonesia are individual selection and family selection activities. Individual and family selection activities aim to improve the phenotype properties of individuals [6]. Improvement of this trait leads to improvement in growth. The main purpose of the selection activity is to produce a parent who has good growth so that the superior trait will be passed down to the resulting saplings. Good growth is more emphasized on increasing weight. The main benchmark for the success of breeding activities is a noticeable increase in fish weight. This increase in weight can be seen from the value of genetic gain obtained. Through selection activities, we will accelerate the genetic increase called "genetic gain". Furthermore, it is said that the value of genetic gain is obtained by comparing the average value of fish selected by $10 \%$ Best among the population or called The Top 10 With average fish value. One example is the improvement in the performance of tilapia Gift 1997 to GET EXCEL 2002 tilapia fish with a genetic gain value of $38.12 \%$. [7,8]. This shows that there has been an improvement in performance from the previous generation. [9].

The individual selection program is conducted by selecting the best $10 \%$ of the population in fish that has reached a measure of consumption in each generation. [5]. Information about the spawning process of fish needs to be obtained to find out the quantity and quality of spawning larvae with different sex ratios. A sex ratio is a number of comparisons of the number of male and female broods in a population. [10]. Research on different sex ratios in tilapia spawning among others states that at the time of colonizing one male tilapia fish can fertilize eggs released by more than one female tilapia fish, so for spawning in the pond the number of female brood should be more than the number of male mothers.[11].

The result of family selection obtained a new tilapia strain that is Nirwana tilapia from Wanayasa. Nirwana tilapia fish have a genetic gain of $12.8 \%$ for females and $30.4 \%$ for males in F2. Genetic gain of $12.8 \%$ for males means that male Nirwana tilapia fish of selection have a growth of $12.8 \%$ better than non-selection nirvana tilapia fish.[6]. Tilapia strain sultana stands for Salabintana Superior Selection. Nila strain Sultana was developed by the Sukabumi Freshwater Aquaculture Fisheries Center (BBPBAT) in 2001, then this tilapia variety received recognition from the KKP with the outside of the Decree of the Minister of Marine Affairs and Fisheries Number KEP.28 / MEN / 2012 on the release of Tilapia Strain Sultana on June 7, 2012. [12]. Tilapia fish generally reach a size of $250 \mathrm{~g}$ requires 5 to 6 months, but tilapia sultana only takes 3 to 4 months, this growth reaches $40 \%$ faster, besides that it has good endurance, and the eggs of this type of fish are more than other fish. Other advantages that tilapia Sultana strains besides fast-growing are fecundity of 3000 to 4500 grains of a kg-1 parent, larvae produced 2542 to $3620 \mathrm{~kg}-1$ brood, FCR 0.73 to 1.12 , resistance to moderate disease, daily growth of 3.67 to $4.25 \%$, and on maintenance ranging from spawning to enlargement has a percentage of survival rate is 70 to $90 \%$. [2].

\subsection{Research Objective}

The purpose of this study is to improve the quality of Tilapia fish seeds produced by the Mina Ayu group of Tabanan Regency Tabanan Village of Bali Province by a selective breeding method.

\section{MATERIALS AND METHODS}

\subsection{Materials}

The material used is the seed of tilapia fish prospective mother of Tilapia Pandu Singapore strain and Larasati strain aged 5 months. The research was conducted using experimental methods of selective breeding (breeding program by selection) with an alternative selection of tilapia parent candidates using individual selection methods. Genetic gain and differential selection result from the average value of the weight of the measured tilapia. The tools used include digital scales, millimeter blocks, and funnel lengths. The seeds of the Janti white tilapia at the age of 4 months have been separated between males and females, each kept for one month in a pond. The seeds of 400 males and 400 females from the pond before being measured were put into the hapa first. The observed research parameters include physical variables (total weight and length), number of live fish, and water quality including dissolved oxygen levels, water temperature, degree of acidity $(\mathrm{pH})$ of water. Measurement data is processed with a specific growth rate formula. The results are analyzed descriptively by comparing. the seeds produced before and after using the master selection method.

\subsection{Parent Selection}

The selected parent candidate comes from the parent stock in the tilapia fish farming pond (Figure 1). Parent selection aims to choose a parent that has good quality to be colonized, to produce good quality and quantity of eggs. The mother is selected manually by visualizing through differences in body shape, genital organs, the body color of male and female fish as well as an examination of the health of selected fish. [13]. The weight of the female parent ranges from 300-400 g / tail, while the weight of the male parent ranges from $400-500 \mathrm{~g} /$ tail.

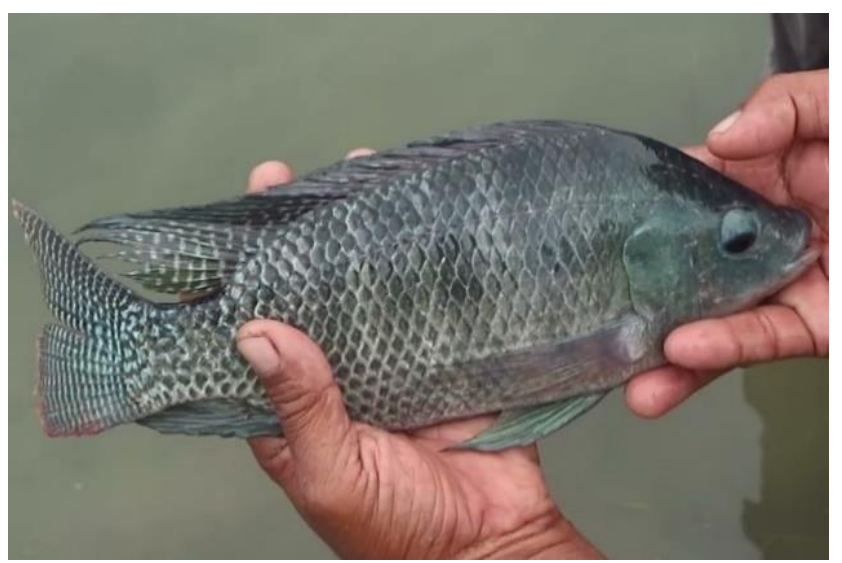

Figure 1. Mother selection of tilapia fish

Differences between male and female tilapia can be seen morphologically, namely body size, the number of holes in the anal part, and the body color of the mother. The characteristics of the male mother have a large and rounded body shape, brighter body-color, genital organs in the form of small and tapered protrusions, and a wider mouth. There are also characteristics of the female mother has a smaller and elongated body shape, faded body-color, concave-shaped genital organs, and a smaller mouth. Method of feeding restricted with FR 1-3\%. The frequency of feeding 2 times a day in the morning at 09.00 and in the afternoon at 15.00. Feeding is done manually, namely, spreading feed near 
the inlet channel in the maintenance pool by using aids in the form of plates. The purpose of feeding that is stocked at one point near the inlet channel in the pond is because tilapia fish gather at the point. [14].

\subsection{Parent Spreading and Spawning}

The selected parent is then released into the spawning pool with a spread density of 1 tail / m (SNI 6141:2009). Mother spreading is done in the morning to avoid temperatures too high that will cause stress on the mother. $[13,15]$. Spawning tilapia in the Mina Ayu Group is done naturally by placing male and female mothers in a unit of spawning pond. Tilapia can colonize yearround in the tropics. [13]. Spawning of fish is done en masse and pairs with a ratio of 1:3. Natural spawning begins with the male mother making a spawning nest with a diameter of $30-50 \mathrm{~cm}$, then the female mother will inhabit the nest that has been made by the male mother until the male mother approaches the female mother and there is a spawning process (the female parent removes eggs and the male parent secretes sperm). The process of spawning tilapia fish takes place very quickly. Within 50 to 60 seconds the female fish can produce 20-40 fertilized eggs. Tilapia spawning occurs in several stages with the same or different pairs. Next, the eggs will be incubated in the mouth of the female mother. The female mother is a mouth breeder (incubating eggs in the mouth). The mother female who is incubating the egg will look enlarged in the mouth. [13].

\subsection{Egg Harvesting and Hatching}

Egg harvesting is done periodically by checking the presence of eggs in the mother's mouth every day. The mother who is incubating the egg is weighed to find out the weight of the female mother before harvesting the egg. The next step after egg harvesting is, the incubation of eggs into containers in the form of plastic basins $30 \mathrm{~cm}$ in diameter with a water level of $50 \%$ of the volume of the container and given aeration. Examination of hatched eggs is carried out periodically. The fertilized tilapia egg will appear transparent and embryonic development occurs, while the unfertilized egg is cloudy white and does not undergo embryonic development at 12 hours after fertilization. The eggs will hatch into larvae after incubating for 48 hours. The larvae are then transferred into a container measuring $2 \mathrm{~m}$ with a water level of $60 \mathrm{~cm}$.[16]. The maintenance of larvae is carried out for 21 days. Fecundity was obtained from one mother tilapia as much as 1,589 grains with FR 95\% and HR 76.7\%. Based on observations, it is known that the diameter of the egg ranges from $1.75 \mathrm{~mm}$ $2.47 \mathrm{~mm}$ with a weight per grain of $1.63 \mathrm{mg}$. Based on KEPMEN KP Number KEP.47 / MEN / 2012, the average number of eggs per parent individual reached 1,773 eggs, FR $91.73 \%$, and HR $81.55 \%$.

\subsection{Larval Harvesting}

Larvae are harvested in the morning at 10:00 and the height of the sun ranges from more than $45^{\circ}$, making it easier to harvest and reduce stress levels in the larvae.[17]. Harvesting of larvae is done by observing the location of the gathering of larvae that can be seen from the surface of the spawning pond by manually scattering the larvae using a net. (Figure 2). Harvesting of larvae is carried out daily in the same spawning pond. The number of larvae obtained in one unit of spawning pond is as much as 30,000-50,000 children. Larvae that have been harvested, are transferred into hapa with net eyes measuring 2-3 $\mathrm{mm}$. The function of hapa larva shelter for sorting containers is because the size of the harvested larvae is not uniform with a maximum shelter length of 5 days.

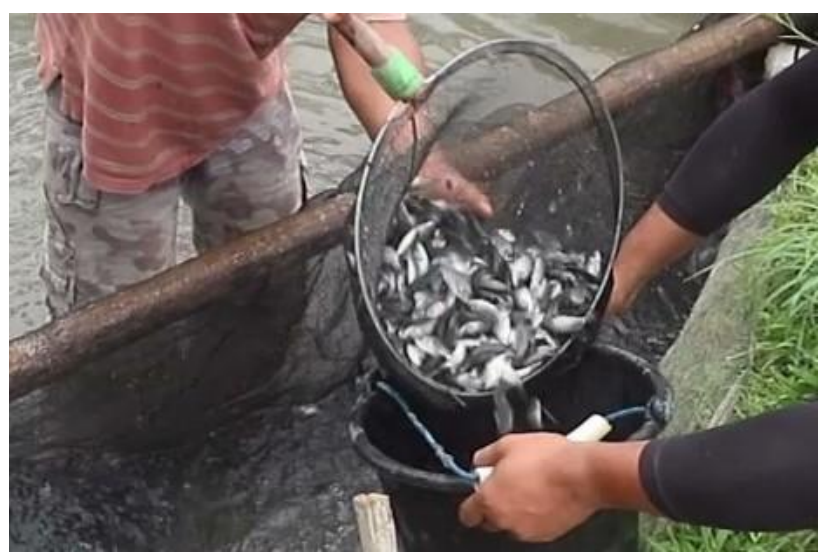

Figure 2. Tilapia seed spawning

\subsection{Larval Maintenance}

The maintenance of larvae is important in the hatchery of fish because of the high mortality. Larvae are the most critical phase of the fish's life cycle. Larvae that have hatched, life is entirely dependent on food sources or energy reserves that have been prepared by their mother. Food sources are given to larvae in the form of drowning feed less than $0.4 \mathrm{~mm}$ in diameter with protein levels of $38-40 \%$. The feed is given to the larvae in the form of a paste that is manually mixed with flour feed with water. Feeding using the method of at satiation with an average total feed of 1 $\mathrm{kg} / \mathrm{day}$. The frequency of feeding three times a day is in the morning at 09.00, noon, and afternoon at 15.00. Measurement of water quality in the larval maintenance pond is carried out every day in the morning and evening.

\subsection{Analytical Method}

\subsubsection{Survival Rate}

The survival rate of larvae is calculated using the formula:

$$
\text { SR }(\%)=\mathbf{N t} / \mathrm{No} \times 100
$$

Where,

$\mathrm{SR}=$ Survival rate $(\%)$

$\mathrm{Nt}=$ Number of fish at the end of maintenance (tail)

$\mathrm{N} 0=$ Number of fish at the beginning of the fishing (tail)

\subsubsection{Absolute Long Growth}

Absolute growth measurements include the absolute length of tilapia larvae carried out on day-1 and day-35 of larval maintenance. Absolute growth length is calculated by the formula:

\section{$\mathbf{L}=\mathbf{L t}-\mathbf{L o}$}

Where,

$\mathrm{L}$ is the absolute long growth ( $\mathrm{mm}$ )

Lo is the length of the fish at the beginning of maintenance $(\mathrm{mm})$

$\mathrm{Lt}$ is the length of the larva at the end of maintenance $(\mathrm{mm})$. 


\subsubsection{Absolute weight growth}

Absolute weight growth is calculated by the formula:

\section{What-Wo}

Where,

$\mathrm{W}$ is absolute weight growth $(\mathrm{mg})$

$\mathrm{Wt}$ is the total weight of the test fish at the end of the experiment (mg)

Wo $=$ Total weight of the test fish at the beginning of the experiment $(\mathrm{mg})$

\subsubsection{Water Quality}

Water quality strengthening is carried out during research activities, namely spawning and maintenance activities of larvae. Water quality measurements include temperature, dissolved oxygen (DO), and degree of acidity $(\mathrm{pH})$.

\section{RESULT AND DISCUSSION}

\subsection{Survival Rate}

The survival rate is the percentage of the number of fish that live from the number of fish during the maintenance period in a given period. During the maintenance period until harvest, the survival rate percentage is (SR) of $80-90 \%$. Fish that die because they are unable to adapt to the new pond environment. and the health condition of the fish. The high survival rate of tilapia larvae indicates that environmental conditions during the maintenance period are in optimal condition for the maintenance of tilapia larvae. Survival values close to $100 \%$ are closely related to the environment and good water quality as well as the ideal biomass and solid spread. $[18,19]$. Low survival rates are thought to be affected by the presence of fish competition in maintenance containers and the rest of the feed that settles into poison. Excessive feeding will settle in the bottom of the pond so that it becomes toxic to fish seeds and result in a decrease in the survival rate of fish seeds. [20]. The poison comes from ammonia which is the result of the protein of the remaining feed and fish manure. [21]. Other factors can affect the survival rate of fish.

\subsection{Long Growth}

Long growth (Figure 3) and absolute weight obtained from the average sampling of tilapia fish larvae, namely the value of length accretion of $1.5 \mathrm{~cm}$ and weight of $0.950 \mathrm{~g} /$ day. Average results of water quality measurements in larval maintenance ponds temperature $25^{\circ} \mathrm{C}-29{ }^{\circ} \mathrm{C}, \mathrm{pH} 6.5-7.2$ and DO 6-6.5 mg / L. Optimal growth in tilapia larvae is in the temperature range of $25^{\circ} \mathrm{C}-33{ }^{\circ} \mathrm{C}, \mathrm{pH}$ 6.0-8.5, and DO 4-7 mg / L [22]. It shows that the water quality in the maintenance media is quite good, so larvae are not susceptible to disease, Stress, and high growth rate. Tilapia spawning and maintenance activities have a $\mathrm{pH}$ range of 6.5-8.6 [23]. The results of DO (Dissolved Oxygen) measurements in spawning containers and fish maintenance range from 5.6-7.6 ppm. Dissolved oxygen content in a medium of tilapia cultivation of at least 4.0 [24]

Sampling activities are carried out at the beginning of the spreading of larvae and during maintenance. Sampling during maintenance is done every week as many as three replications. Sampling is done in the morning to avoid the temperature of hot pool water due to the influence of sunlight [25]. The process of catching larvae for sampling can be done by manual means that spread enough feed to lure larvae to appear on the surface of the pond, then catch them with aids in the form of nets with a diameter of $2-3 \mathrm{~mm}$. The number of larvae at the time of sampling was as many as 30 tails.

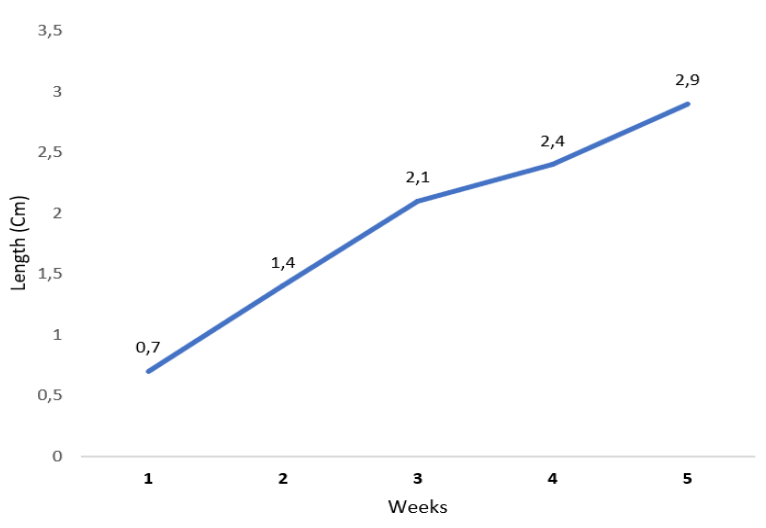

Figure 3. Long growth of tilapia larvae

\section{CONCLUSION}

Based on the results of research and discussion, it can be concluded that individual selection methods applied in the Mina Ayu Group of Baru villages can improve the quality and survival rate of tilapia fish larvae. The absolute length increased by $1.5 \mathrm{~cm}$ and the weight increased $0.950 \mathrm{mg} /$ day with a survival rate of $80 \%$ to $90 \%$. The quality of the pool water during the measurement is still in optimum condition

\section{ACKNOWLEDGEMENT}

The authors thanked the honorable Rector of Warmadewa University and KORPRI Foundation of Bali Province for funding this community service program activities in Baru Village, Tabanan Regency of Bali Province.

\section{REFERENCE}

[1] [KKP] Kementerian Kelautan dan Perikanan. Satu Data Kementerian Kelautan dan Perikanan Produksi Nasional Perikanan Budidaya Tahun 2018. KKP. 2018.

[2] Iskandar A, Islamay R, Kasmono Y. Optimalisasi Pembenihan Ikan Nila Merah Nilasa Oreochromis sp. Di Ukbat Cangkringan, Yogyakarta. Samakia. J Ilmu Perikan. 2021;12(1):29-37.

[3] Mulyani YS, Yulisman, Fitriani M. Pertumbuhan dan efesiensi pakan ikan nila (Oreochromis niloticus) yang dipuasakan secara periodik. J Akuakultur Rawa Indones. 2014;2(1):1-12.

[4] Murniyati, Dewi F., Paranginangin R. Teknik pengolahan tepung kalsium dari tulang ikan nila. Jakarta: Penebar Swadaya; 2014. 74 p.

[5] Nugroho E, Rustadi, Priyanto D, Sulistyo H, Sunaryo, Wasito B. Penurunan keragaman genetik pada F-4 ikan nila merah "Cangkringan" hasil pemuliaan dideteksi dengan marker genetik. J Ris Akuakultur. 2014;9(1):2530.

[6] Gustiano R, Otong Zaenal A, Nugroho E. Perbaikan Pertumbuhan Ikan Nila (Oreochromis niloticus) dengan Seleksi Famili. Media Akualkultur. 2009;3(2):98-106. 
[7] Tave D. Selective Breeding Programmes for MediumSized Fish Farmer. Food and Agricultural Organization. Oregon, USA: Uraina Unlimited Coos bay; 1995. 352 p.

[8] Doyle RM, Perez-Enriquez R, Takagi M, Taniguchi N. Selective recovery of founder genetic diversity in aquacultural broodstocks and captive, endangered fish populations. Genetica. 2001;111(1):291-304.

[9] Yuniarti T, Hanif S, Hardianthi D. Penerapan Seleksi Famili F3 Pada Ikan Nila Hitam (Oreochromis niloticus). J Saintek Perikan. 2009;4(2):1-9.

[10] Novianto D, Nugraha B, Bahtiar A. Komposisi ukuran, perbandingan jenis kelamin, dan tingkat kematangan gonad ikan todak berparuh pendek (Tetrapturus angustirostris) di Samudera Hindia. J Bawal. 2010;3(2):123-8.

[11] Kordi MGH. Panduan Lengkap Memelihara Ikan Air Tawar di Kolam Terpal. Yogyakarta: ANDY; 2010. 280 p.

[12] [KKP] Kementerian Kelautan dan Perikanan. Keputusan Menteri Kelautan dan Perikanan Nomor KEP.47/MEN/2012 tentang Pelepasan Ikan Nila Merah Nilasa. KKP. 2012.

[13] Sumarni. Penerapan fungsi manajemen perencanaan pembenihan ikan nila (Oreochromis niloticus) untuk menghasilkan benih ikan yang berkualitas. J Galung Trop. 2018;7(3):175-83.

[14] Hidayat K., Prabowo D., Amelia D. Natural Breeding of Snakehead Fish (Channa striata) On Concrete Ponds in Cangkringan Center for Aquaculture Technology Development Special Region of Yogyakarta. Samakia: Jurnal Ilmu Perikanan. J Ilmu Perikan. 2019;10(2):83-93.

[15] Hidayat A. Potensi Pembesaran Ikan Nila Merah (Oreochromis sp.) Kolam Air Deras Di Daerah Irigasi Banjaran, Purwokerto, Jawa Tengah. Samakia. J Ilmu Perikan. 2018;9(1):12-7.

[16] Nainggolan. Penambahan madu dalam pengenceran sperma untuk motilitas spermatozoa, fertilisasi dan daya tetas telur ikan nila (Oreochromis niloticus). J Budid Perair. 2015;3(1):131-40.
[17] Tiani, Narayana Y. Teknik pemeliharaan larva ikan nila Genetically Male Tilapia GMT (Oreochromis niloticus) di Balai Besar Pengembangan Budidaya Air Tawar (BBPBAT) Sukabumi, Jawa Barat. J Pengetah dan Teknol. 2018;1(2):52-62.

[18] Ronald N, Gladys B, Gasper E. The effects of stocking density on the growth and survival of nile tilapia (Oreochromis niloticus) fry at son fish Farm, uganda. J Aquat Resour Dedvelopment. 2014;5(2):1-7.

[19] Malik A, Abbas G, Ghaffar A, Ferrando S, Gallus L, Shah SS. Effect of different salinity level on breeding, fertilization, hatching and survival of Nile Tilapia, Oreochromis niloticus (Linnaeus, 1758) in captivity. Pak J Zool. 2018;50(2).

[20] Purbamartono C, Hanoyo., Kundawan A. Pertumbuhan kompensasi pada ikan nila merah (Oreochromis niloticus) dengan interval waktu pemuasaan yang berbeda. J Fish Sci. 2009;II(I):19-24.

[21] Arifin MY. Pertumbuhan dan survival rate ikan nila (Oreochromis sp.) strain merah dan strain hitam yang dipelihara pada media bersalinitas. J Ilm Univ Batanghari Jambi. 2016;16(1):159-66.

[22] Suyanto SR. Pembenihan dan Pembesaran Nila. Jakarta: Penebar Swadaya; 2011. 105 p.

[23] Salsabila M, Suprapto H. Teknik Pembesaran Ikan Nila (Oreochromis niloticus) di Instalasi Budidaya Air Tawar Pandaan, Jawa Timur. J Aquac Fish Heal. 2018;7(3):11823.

[24] Pramleonita M, Yuliani N, Arizal R, Wardoyo S. Parameter fisika dan kimia air kolam ikan nila hitam (Oreochromis niloticus). J Sains Nat Univ Nusa Bangsa. 2018;8(1):24-34.

[25] Kurnia R, Widyorini N, Solichin A. Analisis kompetisi makanan antara ikan tawes (Barbonymus gonionotus), ikan mujair (Oreochromis mossambicus) dan ikan nila (Oreochromis niloticus) di perairan Waduk Wadaslintang Kabupaten Wonosobo. J Manaj Sumberd Perair. 2017;6(4):515-24. 